\title{
SYSTEMATIC DIFFERENCES IN CONSONANT SOUNDS BETWEEN THE INTERLANGUAGE PHONOLOGY OF A BRAZILIAN PORTUGUESE LEARNER OF ENGLISH AND STANDARD AMERICAN ENGLISH
}

Denise M. Osborne

Teachers College - Columbia University

\section{Abstract}

This study surveys the interlanguage phonology of a Brazilian learner of English who has primarily learned English in a naturalistic environment. The phonological analysis of her speech shows that native language transfer is a strong source of pronunciation difficulties, constraints, and deviations. However, other factors seem to play a relevant role in this learner's interlanguage, such as sounds that are universally considered difficult to acquire. Interestingly, some of the phonological strategies applied by the participant are not unique to an interlanguage but are also applied by native speakers. Considerations about possible miscommunication are addressed. Keywords: Brazilian Portuguese, English as a second language, interlanguage phonology.

\section{Introduction}

This study aims to investigate systematic differences in consonants between standard American English and an interlanguage (IL)

\begin{tabular}{|l|l|l|l|l|}
\hline Ilha do Desterro & Florianópolis & no 55 & p. 111-132 & jul./dez. 2008 \\
\hline
\end{tabular}


phonology produced by a speaker whose first language is Brazilian Portuguese (BP). Attempts to explain some of the differences will be addressed, for example, taking into consideration constraints from the speaker's first language (L1) as well as considerations from the framework of markedness theory.

Many studies on IL of BP learners in instructional settings have been conducted (e.g., Key, 2002; Delatorre \& Koerich, 2004; Cruz, 2005); very few, however, in a naturalistic environment (e.g., Baptista, 1992). This paper aims to help better understand the IL systems of such learners. Considerations concerning whether certain features of the IL would likely lead to communication problems are also addressed. The article begins with a brief review of the literature, followed by the methodology employed in the study, and the result section. The paper concludes with some suggestions for future investigations.

\section{Literature review}

The study of IL phonology goes back to Lado (1957) and his Contrastive Analysis Hypothesis (CAH), which states that it is possible to predict learners' errors by comparing L1 and the target language (TL). According to Lado, structures in the TL that are different from the L1 are more difficult to acquire. The $\mathrm{CAH}$, however, proved to be inaccurate in some of its predictions and not able to explain all errors produced by learners.

Error analysis emerged from the critics of the $\mathrm{CAH}$. Error analysis is not interested in predicting errors, but rather in analyzing errors that occur in the IL system. Although it represents an advance in the study of IL, error analysis has been criticized as well, mainly because it overemphasizes what learners do wrong (Celce-Murcia, Briton, \& Goodwin, 1996).

The analysis of learners' errors has gained different perspectives, moving away from the idea that errors represent inability or laziness to produce the target language. Corder (1967) emphasizes the importance of learners' errors as a way of testing hypotheses of second language 
(L2) knowledge. This process of testing hypotheses has possible different sources of knowledge, such as the learners' attempt to apply phonological rules from their L1 in the L2 or when learners overgeneralize phonological rules of L2. Surfacing an interdental [t $\mathrm{t}]$, for example, instead of the stop [t] in words such as 'team', may show that the learner is in a process of constructing his or her IL by testing hypotheses about the L2. Producing an interdental instead of a stop may show that the learner is able to recognize the interdental as well as produce it. It may be seen as an overcompensation for sounds that are difficult (Lightbown \& Spada, 2006). As learners receive more and more input, they revise their hypotheses about the target language, a gradual progress which approximates the learners' IL to the target system.

Interlanguage, as defined by Selinker (1972), is the learner's development of their second language (L2) knowledge. The study of ILs has shown that they surface characteristics of L1s, or other languages previously learned, as well as characteristics of L2s. Research has also shown that ILs have characteristics that are more general, and are independent from the L1, such as the omission of functional words (Lightbown \& Spada, 2006). According to Selinker, ILs are independent and unique systems. Such systems are "based on the observable output which results from a learner's attempted production of target language norm" (p. 214). IL is a continuum and a dynamic process in which learners move toward the target language as they receive input and redefine their hypotheses (Corder, 1974, as cited in Celce-Murcia et al., 1996).

Markedness theory has contributed to the field of second language acquisition (Celce-Murcia et al., 1996). According to this approach, unmarked linguistic features are more neutral, universal and frequent whereas marked linguistic features are more specific and less frequent. Unmarked features are acquired earlier than marked features. Eckman (1977) proposed the Markedness Differential Hypothesis (MDH), in which markedness theory is applied to second language phonology acquisition. It claims that $\mathrm{L} 2$ learners will acquire unmarked structures faster than marked ones. 
The investigation of IL phonology of learners whose L1 is BP has shown that L1 does interfere in their IL phonology (e.g., Keys, 2002). There is evidence that BP learners of English transfer coda constraints into their IL and that BP learners have a tendency to add an epenthetic vowel to words ending in <ed> (e.g., Monahan, 2001; Koerich, 2002; Delatorre \& Koerich, 2004). Other studies have focused on the interference of orthography in the pronunciation of BP learners of English (e.g., Silveira, 2007). A comprehensive analysis of theses and dissertations of Brazilian graduate programs between 1987 and 2004 shows that perception and production of segments and syllables, intonation and rhythm, and the teaching of English pronunciation, among other topics, have been investigated within various theoretical frameworks (Silveira \& Baptista, 2007). Most of these studies have been conducted with learners of English in an instructional setting. This article aims to contribute to a better understanding of the complexity of IL phonology of BP learners of English by investigating the IL of a learner who has acquired the language mostly in a naturalistic environment.

The present study investigates systematic differences between standard English and the IL phonology of a Brazilian learner of English, focusing on the consonant sounds. These differences are related to the devoicing of final obstruents and the surface manifestation of consonant clusters, as well as interdentals, initial voiceless aspirated stops, final stops, the retroflex liquid, the syllabic $/ 1$ / and the dark / $1 /$. Attempts to explain these differences are addressed, as well as considerations regarding possible miscommunication.

\section{Methodology}

The participant was a middle-aged woman from the state of Minas Gerais, who moved to New York six years before the time that this study was conducted. By the time of data collection, she was studying English in the Community English Program at Teachers College Columbia University. Before she started her classes, she took a 
placement test and was placed in the low intermediate level. When the data was collected, she had had only around four months of formal English instruction, attending six hours of classes per week, a total of approximately 96 hours of formal instruction. She said that she had had some basic English classes in a public high school in Brazil when she was younger. However, she claimed that she really did not know English and her proficiency level was indeed very low when she moved to New York. Most of her learning in the city occurred in a naturalistic environment. In the study, she was invited to speak in a spontaneous way on a subject of her choice for twenty minutes. A list of topics was suggested; however, she could talk about anything she wanted. The topics were: family, her life as an immigrant, her daily routine, positive and negative aspects of living in New York, and her plans for the future. The researcher was prepared to interact with her, in case some cueing was needed to keep her talking. However, this was not necessary. The participant's speech was tape-recorded. Only the first part of her speech was transcribed by the researcher (the first 7 minutes and 6 seconds). The time limit was an arbitrary decision since the researcher felt that she had already enough data to work with. The phonological transcription was then checked by a more experienced researcher in the field. Tables with transcriptions taken from the participant's speech were prepared to show the difference between her IL and standard English.

\section{Data analysis and discussion}

\subsection{Devoicing of final obstruents}

Stops, fricatives, and affricates are called obstruents because they share an articulatory feature: they "involve an obstruction of the airstream" (Ladefoged, 2006, p. 65). Obstruents may be voiceless or voiced in word-final position in English.

In $\mathrm{BP}$, the following voiceless and voiced obstruents can occur at the end of words: alveolar fricatives /s/ and / $\mathrm{z}$, glottal fricatives / $\mathrm{h} /$ and $/ \mathrm{h} /$, and velar fricatives $/ \chi /$ and $/ \mathrm{\gamma} /$ (typical pronunciation of 
the city of Rio de Janeiro) (Cristófaro Silva, 2007). In the dialect of Rio de Janeiro final alveolar fricatives surface as palatal fricatives $[\chi]$ and [y], respectively (Cristófaro Silva). What determines if final alveolar fricatives are voiced or voiceless is the following phoneme sound. Regressive voicing assimilation occurs as follows: if the obstruent is followed by a voiced sound, the obstruent will be voiced; if the obstruent is followed by a voiceless sound, the obstruent will be voiceless. For example, 'faz bolo' (He/she makes a cake) surfaces as ['faz 'bolU] and 'faz calor' (It is hot) surfaces as ['fas kalox]. However, "in absolute final position, the obstruents are voiceless" (Faria, 2003, p. 8).

As Table 1 shows, the participant has a tendency to devoice obstruents at the end of words. However, not all final obstruents are devoiced, which seems to show that she is able to produce some voiced final obstruents. Nonetheless, most of the words ending in voiced obstruents are devoiced. It is important to point out that the participant almost never produces linking between words. She pronounces the words separately, with pauses between words, which constitutes evidence of a lack of fluency.

\section{Table 1}

Devoicing of Final Obstruents ${ }^{\mathrm{a}}$

\begin{tabular}{l|l|l|l}
\hline Phonemes & Total of words & Target like & Devoicing \\
\hline /d/ & 14 & $8(57 \%)$ & $6(43 \%)$ \\
/v/ & 13 & $5(38 \%)$ & $8(62 \%)$ \\
/z/ & 13 & $3(23 \%)$ & $10(77 \%)$ \\
/d3/ & 4 & & $4(100 \%)$ \\
\hline
\end{tabular}

a The word and is not included because of the overwhelming number of instances the participant produced that word in her speech.

Most of the devoicing of final obstruents occurs with [v], as in respective, which surfaced as [ho'si ptif]; [z], as in because, which surfaced as [bi'kos]; and [d], as in understand, which surfaced as [əns'tent]. 
Only two words with final $/ \mathrm{d}_{3} /$, each repeated twice, are produced by the participant and both are devoiced. The words are 'marriage' and 'language,' which surfaced as ['merjt]] and ['lingwat'] respectively.

Regarding the final $\langle n g\rangle$, the only word produced by the participant was things, which surfaced as ['tinks]. It may be hard for learners to distinguish $/ \mathrm{gg} /$ and $/ \mathrm{gk} /$ from $/ \mathrm{y} /$ (Celce-Murcia et al., 1996). This is probably what happens with this learner. This is also in accordance with the participant's tendency to devoice final obstruents.

The participant varies the way she produces the final alveolar stop [d] when she pronounces the word husband. Sometimes, husband surfaces as ['hasband], sometimes devoicing occurs, and ['hasbant] is surfaced. Twice in her speech, the participant deletes the final alveolar stop, producing husband as ['hasban]. It seems that, at least for the word husband, free variation occurs since it is non-systematic.

The process of devoicing is particularly interesting because it is not directly linked with the phonological rules of Portuguese. According to Archibald (1998), the devoicing of final obstruents is also found in other languages, such as German, and it is found "in children acquiring English as an L1" as well (p. 4).

Yavas (1994) argues that, for languages that do not permit stops in final position, such as Portuguese and Japanese, three processes are possible: deletion, epenthesis, and devoicing. Although one may argue that L1 may be responsible for deletion and epenthesis, Yavas asserts that devoicing is a universal and independent tendency because it is a common process in L1 and L2 and its patterns are found in different languages of the world.

A question may be raised: Would it be the case that for speakers of different first languages, devoicing is a natural process in language acquisition in which the speaker, learning a second language, goes through developmental sequences, realizing voiced obstruents as voiceless first and, later, acquiring the voiced counterpart?

Most languages have three voiceless stops $(/ \mathrm{p} /, / \mathrm{t} /, / \mathrm{k} /)$ which may suggest that they are more basic than other stops (Finegan, 2004). Portuguese has these three voiceless stops and their voiced counterparts. 
Some languages, such as Korean and Mandarin Chinese, have only voiceless stops. Languages that have the voiced stops also have their voiceless counterparts (Finegan). Therefore, we can conclude that voiceless stops are less marked than voiced stops.

According to the Structural Conformity Hypothesis, proposed by Eckman (1991, as cited in Yavas, 1994), "universal generalizations that are valid for first languages also hold for interlanguages" (p. 268). Therefore, according to this hypothesis, the process of devoicing is expected in ILs because it is observed in L1 acquisition.

On the other hand, it may be argued that a more complicated phonological rule is developed in the interlanguage with allophonic variants that do not belong to the L2. Some aspects of IL phonology may be similar to L1 acquisition in terms of developmental sequences and in terms of the universal nature of phonological acquisition (CelceMurcia et al., 1996). Longitudinal studies would help to investigate possible developmental sequences in ILs of learners of English.

One may argue that the devoicing of final obstruents leads to miscommunication because voiceless and voiced obstruents occur in contrastive distribution in English. For example, the participant says ['tipks] for things. A native speaker of English would perceive such words as thinks. However, Ladefoged (2006) points out that voiced obstruents - stops and fricatives - "are voiced through only a small part of the articulation when they occur at the end of an utterance or before a voiceless sound" (p. 72). Ladefoged gives the example of / v/ in the phrase try to improve, and of the $/ \mathrm{d} /$ in add two. Devoicing is not the only source of misunderstanding when the context provides clarity. However, no (or very few) pronunciation mistakes cause misunderstandings if the context helps to define the word.

4.2. Consonant clusters in initial and final positions in a syllable

English permits more consonant clusters in a syllable than Portuguese. Therefore, it is interesting to see how the participant would produce clusters which are not permissible phonologically in Portuguese. 
English permits two consonant clusters in syllable onsets in which either the first phoneme is an obstruent or the second is an approximant. When the first consonant is /s/, it can be followed by voiceless stops, nasals (except $/ \mathrm{y} /$ ), or approximants (e.g., snake surfaces as ['sneyk]. English also allows three consonants, which have to follow this sequence: /s / + voiceless stop + approximant (e.g., spring surfaces as ['sprin]) (Celce-Murcia et al., 1996). In consonant clusters in the coda, English allows more consonant clusters than in initial position. The clusters can consist of up to four consonants, as in texts, surfaced as ['teksts] (Celce-Murcia et al.).

$\mathrm{BP}$, on the other hand, has more restrictive rules regarding consonant clusters. In consonant clusters in syllable onset, BP allows only a stop or a fricative /f/ or / $/$ / followed by a liquid / $/$ / or a flap / $/$ /. (e.g., livro is realized as /'livro/). / $\mathrm{dl} /$ does not occur and /vl/ only occurs in foreign names. $/ \mathrm{vr} /$ and $/ \mathrm{tl} /$ do not occur at the beginning of a word (Cristófaro Silva, 2007).

Regarding the consonant clusters in postvocalic position, BP is very restrictive. Only one consonant, represented by the archiphonemes $/ \mathrm{S} /, / \mathrm{f} /, / 1 /$, and $/ \mathrm{y} /$, is generally allowed in postvocalic position. Two consonants in postvocalic position are possible as long as the first consonant is one of the archiphonemes $/ \mathrm{f} /, / 1 /$, or $/ \mathrm{y} /$ followed by $/ \mathrm{s} /$ (e.g., solstício is realized as / sol $\int^{\prime}$ tisio/) (Cristófaro Silva, 2007). It is important to notice that, according to Mattoso Câmara Jr. (1984), nasal vowels consist of an oral vowel followed by the archiphoneme /y/ (e.g., 'sim' (yes) is realized as /siy/ ['sĩ]). Following this view, we consider nasal vowels as having a structure of a closed syllable (Cristófaro Silva). Therefore, nasal vowels followed by $/ \mathrm{S} /$ result in a cluster (e.g. 'uns' (some) surfaces as /uyf/ [ũns]).

The results summarized in Table 2 show that the participant does not have any problem in pronouncing words that follow the Portuguese phonological rule for syllable onset, such as place [pl] and country [tr]. The only alteration is that $/ \mathrm{r} /$, after the stops, is pronounced as a flap. In Portuguese, the rhotic preceded by a consonant in the same syllable is realized as a flap [r] in any dialect (Cristófaro Silva, 2007). The word 'prato' 
(plate), for example, surfaces as ['pratu]. The participant has a tendency to produce a flap in consonant clusters in syllable onsets, which indicates that she transfers the phonological rule from Portuguese to the TL.

\section{Table 2}

Consonant clusters

\begin{tabular}{l|l|l|l|l|l}
\hline $\begin{array}{l}\text { Consonant } \\
\text { cluster }\end{array}$ & Total words & Target like & Reduction & $\begin{array}{l}\text { Epenthesis } \\
\text { [ə] and [i] }\end{array}$ & $\begin{array}{l}/ \mathrm{r} / \text { surfaced } \\
\text { as [r ] }\end{array}$ \\
\hline $\begin{array}{l}\text { Onset } \\
\text { Coda }\end{array}$ & 32 & $\begin{array}{l}13(41 \%) \\
5(42 \%)\end{array}$ & $4(33 \%)$ & $3(25 \%)$ & $19(59 \%)$ \\
\hline
\end{tabular}

In the syllable coda, there is more variation. When the participant produces a 3-member consonant cluster, which is not permitted in her L1, she almost always drops the last consonant, making the consonant cluster easier to pronounce and simplifying the cluster, a strategy called cluster reduction. Examples from the participant's speech are first, surfaced as ['fərs] and next, surfaced as ['neks].

At other times, the participant inserts a final vowel, creating more syllables, a strategy called epenthesis. Vowel insertion is also a strategy used by native speakers of BP when they encounter impermissible clusters in their L1. They tend to add a high front vowel, breaking down the cluster. For example, for the word 'advogado' (lawyer), Brazilians surface it as [adivo'gadu]. It may be argued, therefore, that the participant is applying the same strategy in her IL. This occurs with

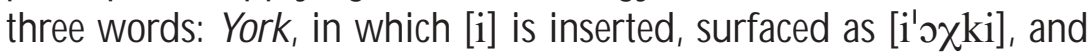
with find and start, in which a schwa is inserted after the final stops.

Adding a phoneme or dropping a consonant in clusters might cause problems in communication. When the participant says, for example, ['neks] for next, she is actually conveying another meaning. However, cluster reduction is also a strategy applied by native speakers in order to simplify clusters (e.g., fifths may be reduced from ['fif $\theta$ s] to 
[fifs]) (Celce-Murcia et al., 1996, p. 83). Therefore, although technically miscommunication could occur, it may not be so outlandish. The use of epenthesis, however, marks the speaker as a non-native. Producing a flap instead of a retroflex in a syllable onset does not cause serious problems in communication; however, native speakers may associate it with a foreign accent.

\subsection{Interdentals}

Replacing interdentals with other sounds seems to be common for speakers of languages whose inventory lacks the interdentals. Quebec French speakers, for example, have the sound /ð/ replaced with [d]. European French, however, replaces the interdental / $/$ with /z/ (Archibald, 1998). Interdentals are not part of the BP inventory. The participant, then, applies a replacement strategy in her IL, as can be seen in Table 3.

\section{Table 3}

Interdental Fricatives

\begin{tabular}{l|l|l|l}
\hline Phoneme & Total words & Surfaced as $[\mathrm{t}]$ & Surfaced as [d] \\
\hline$[\theta]$ & 23 & $23(100 \%)$ & \\
$/$ ठ $/$ & 25 & & $25(100 \%)$ \\
\hline
\end{tabular}

The participant's output shows that the voiceless interdental $/ \theta /$ is replaced with a voiceless alveolar stop $[t]$ and that the voiced interdental $/ ð /$ is replaced with a voiced alveolar stop [d]. The participant maintains this replacement systematically during all her speech.

Replacing the interdentals with stops might cause misunderstanding. Both sounds occur in contrastive distribution in standard English. By changing the phonemes, the speaker conveys different meanings (e.g., thanks ['Өæyks] and tanks ['tæyks]). However, this may not be seen as a major problem because there are dialects of English that replace the interdentals with $[t]$ and $[d]$. The 
English dialect called African American Vernacular English (AAVE), spoken by someAfrican American communities, including New York's, does produce the interdentals (or dentals) as [t], [d], [f], and [v] on a regular basis (Finegan \& Rickford, 2004).

\subsection{Initial voiceless aspirated stops}

According to Eckman (1977, as cited in Archibald, 1998), structures which are more marked are more difficult to acquire and develop. Aspirated consonants are more marked than nonaspirated ones and, therefore, more difficult to acquire. Initial voiceless stops are not aspirated in Portuguese as well as in many other languages, and, as expected, the participant does not aspirate the initial English stops.

Celce-Murcia et al. (1996) argue that failing to aspirate /p/, /t/, and $/ \mathrm{k} /$ in stressed syllables in initial position can cause confusion among native speakers because they can perceive the voiceless stops as being their voiced counterparts. However, several native speakers have informally reported that they do not perceive this as a serious problem and that it may not lead to miscommunication. As for the data in the present study, two native speakers who heard the participant's recording do not report any miscommunication or confusion regarding the non-aspiration of initial voiceless stops. Nevertheless, it marks the speaker as non-native.

\subsection{Final stops}

In casual speech, the final voiceless and voiced stops are often not released in final position, in most English dialects. The articulation process is not completed and deletion of the release occurs. When final stops are followed by a vowel, linking or resyllabification may take place (Celce-Murcia et al., 1996). The participant, however, releases the final stops most of the time, followed by a pause, at times adding a weak schwa [ə] or a high front vowel [i] after the consonant. At other times, she deletes them. These results are summarized in Table 4. 


\section{Table 4}

Surfacing final stops

\begin{tabular}{l|l|l|l|l|l|l}
\hline $\begin{array}{l}\text { Final } \\
\text { stops }\end{array}$ & $\begin{array}{l}\text { Total } \\
\text { words }\end{array}$ & Released & Deletion & Linking & Epenth. [Y ] & Epenth.[i] \\
\hline$[\mathrm{t}]$ & 20 & $12(60 \%)$ & $5(25 \%)$ & & $3(15 \%)$ & \\
{$[\mathrm{d}]$} & 20 & $12(60 \%)$ & $3(15 \%)$ & $2(10 \%)$ & $\begin{array}{l}3(15 \%) \\
3(17.5 \%)\end{array}$ & $3(17.5 \%)$ \\
\hline $\mathrm{k}]$ & 17 & $11(65 \%)$ & & & $35 \%$ \\
\hline
\end{tabular}

Although the participant releases the final stops most of the time, she occasionally inserts a schwa, such as in bit, surfaced as ['bitə], up, surfaced as ['apə], and like, surfaced as ['laykə]. The insertion of the [i] sound after final stops occurs only with two words ending in [k]: York and speak, surfaced as [i'oxki] and [s'piki] respectively. The deletion of final stops occurs with [d] only in some instances of the word husband. The final stop [t] is deleted in the words about, first, and next. Linking occurs only in two instances when she produces a liaison between good and the following word which starts with a stop: good time and good thing, surfaced as ['gutaym] and ['gutink]. This type of linking is produced by native speakers as well. It happens when "a stop consonant is followed by another stop or by an affricate and, the first stop is not released" (Celce-Murcia et al., 1996, p. 159). However, linking does not occur in other instances of the participant's speech. It is possible that the participant has acquired these phrases as chunks.

When the final stops are not released, miscommunication does not occur because native speakers rely on the length of the vowel that precedes the stops to distinguish between final voiced and voiceless stops: before voiceless stops, the vowel is shorter than before voiced stops (Ladefoged, 2006). Therefore, the vowel length distinguishes word pairs, such as kid and kit.

The way the participant releases final stops does not seem to represent a serious problem in communication. According to CelceMurcia et al. (1996), the tendency to unrelease final stops is more 
representative of North American English than of British English. Therefore, depending on the dialect, some variation is expected.

\subsection{Retroflex liquid}

In Portuguese, the orthographic ' $r$ ' can be pronounced as glottal fricatives [h], velar fricatives $[\chi, \gamma]$, a retroflex liquid ["] , or a flap $[r]$, depending on its position in a word as well as on the dialect. Glottal fricatives, velar fricatives, and the retroflex liquid, called / $/$ postvocalic, are allophones when they occur in syllable-final position. The retroflex rhotic / $\mathrm{r}$ / occurs in some dialects of Portuguese (Cristófaro Silva, 2007). It is called ' $r$ caipira' ('hillbilly $r$ '). The glottal fricatives and velar, on the other hand, are part of the BP inventory and are considered standard pronunciation.

Between vowels, in word-final position, and in syllable-initial position when preceded by a consonant, the orthographic ' $r$ ' can surface as $[\mathrm{h}, \chi]$, called the strong / $\mathrm{r} /$. These phonemes are allophones of / $\mathrm{r} /$ and represent possible dialect variation in BP (Cristófaro Silva, 2007). They are non-contrastive and occur in free variation. While glottal fricatives may be considered more standard, velar fricatives are typically from the city of Rio de Janeiro. The trill is pronounced only in the extreme south of Brazil (Cristófaro Silva, 2007).

The flap, called weak 'r,' occurs between vowels and after a consonant in the same syllable. The strong ' $R$ ' and the weak ' $r$ ' occur in contrastive distribution when in intervocalic position in Portuguese; that is, when replacing one phoneme with the other, the meaning of the

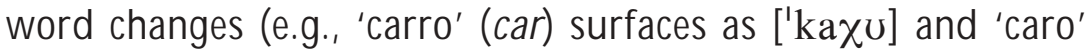
(expensive) surfaces as ['karu]) (Cristófaro Silva, 2007, p. 142).

The rhotic, therefore, can surface as $[\mathrm{h}],[\chi]$, as well as their counterparts [h] and [y], and as a flap [r]. It can also surface as a retroflex liquid $[\mathrm{I}]$ and a trill in certain dialects, as mentioned before.

In English, however, glottal fricatives and the alveolar retroflex do not occur in free variation (e.g., hope [howp] and rope [rowp]). BP learners of English may find it difficult to understand cross-linguistic phonological differences. They may consider glottal fricatives and the 
alveolar retroflex as variants of the same phoneme in English when, in fact, they are allophones of different phonemes. Tables 5 to 8 display the results for the retroflex liquid / $\mathrm{I} /$ in different phonological environments.

\section{Table 5}

Retroflex liquid / $\mathrm{I} /$ in syllable-final position

\begin{tabular}{l|l|l|l|l}
\hline Syllable-final & Target like & $/ \mathrm{r} /$ surfaced as $[\chi]$ & $/ \mathrm{r} /$ surfaced as $[\mathrm{h}]$ & $\begin{array}{l}\text { Dropping } \\
\text { final } / \mathrm{r} /\end{array}$ \\
\hline 46 & $16(35 \%)$ & $3(7 \%)$ & $13(28 \%)$ & $14(30 \%)$ \\
\hline
\end{tabular}

Table 5 shows that in syllable-final position, the participant varies the way she realizes the retroflex $/ \mathrm{x} /$. Although in some instances $/ \mathrm{r} /$ is realized as target-like, the participant also realizes it as $[\mathrm{h}]$ or $[\chi]$, such as in far and normally, realized as ['fax] and ['no hmoli]. She also drops the $/ r /$ in word-final position, such as in more, which she surfaces as ['mo].

\section{Table 6}

Retroflex liquid / $\mathrm{I} /$ in syllable-initial position

\begin{tabular}{l|l|l|l}
\hline Syllable-initial & Target like & $/ \mathrm{r} /$ surfaced as $[\mathrm{h}]$ & $/ \mathrm{r} /$ surfaced as $[\mathrm{r}]$ \\
\hline 17 & $11(65 \%)$ & $3(17.5 \%)$ & $3(17.5 \%)$ \\
\hline
\end{tabular}

In syllable-initial position, as shown in Table 6, the retroflex liquid sometimes surfaces as target-like, sometimes as [h] and still other times as [h]. For example, relax surfaces as [hi'laks] and the only instance in which she realizes $/ \mathrm{r} /$ as a flap is in the word there's, realized as ['deriz].

Table 7 shows that when $/ \mathrm{r} /$ is preceded by a stop in a cluster in the onset, most of the time the participant realizes it as a flap, such as in try, which is surfaced as ['tray]. Finally, Table 8 indicates that the participant's output varies when the retroflex is followed by a consonant 
in a cluster in coda. Sometimes, it surfaces as $[\mathrm{h}]$ or $[\chi]$, such as in hard and course, realized as ['ha $\chi \mathrm{d}]$ and ['kohs]. In one instance, the retroflex was dropped in the word start, which surfaced as ['sta:t].

\section{Table 7}

Retroflex liquid / $/$ / in clusters in syllable onset: stop $+/ \mathrm{r} /$

\begin{tabular}{l|l|l}
\hline Stop $+/ \mathrm{r} /$ & Target like & $/ \mathrm{r} /$ surface as $/ \mathbf{r} /$ \\
\hline 25 & $7(28 \%)$ & $18(72 \%)$ \\
\hline
\end{tabular}

\section{Table 8}

Retroflex liquid / $\mathrm{I} /$ in clusters in syllable coda: $/ \mathrm{r} /+$ consonant

\begin{tabular}{l|l|l|l|l}
\hline $\begin{array}{l}\text { Consonant } \\
+/ \mathrm{r} /\end{array}$ & Target like & $\begin{array}{l}/ \mathrm{r} / \text { surfaced } \\
\text { as }[\chi]\end{array}$ & $\begin{array}{l}/ \mathrm{r} / \text { surfaced } \\
\text { as }[\mathrm{h}]\end{array}$ & Dropping $/ \mathrm{r} /$ \\
\hline 8 & $3(37.5 \%)$ & $3(37.5 \%)$ & $1(12.5 \%)$ & $1(12.5 \%)$ \\
\hline
\end{tabular}

She also does not have problems when realizing a flap between vowel sounds, as in city, little, and better, which she realizes as ['siri], ['liro], and ['berə]. She also realizes the initial glottal /h/. In both cases, BP and English share a similar phonological rule: Portuguese, as well as English, has the $[\mathrm{h}]$ sound in the beginning of a syllable followed by a vowel (however, depending on the BP dialect, the variant $[\chi]$ may surface, as in the dialect of Rio de Janeiro (e.g., 'rio' (river) surfaces as

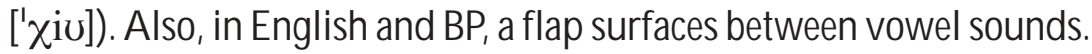
In Portuguese, a flap can occur in either stressed or unstressed syllables (e.g., 'arara' (macaw) surfaces as ['arara] - the flap occurs in the stressed and unstressed syllables in this word) (Cristófaro Silva, 2007). In English the flap only occurs in an unstressed syllable, preceded by a stressed syllable (e.g., butter surfaces as ['bıгər]). It may be argued that these three words, city, little, and better, have been acquired in a target-like fashion due to their high frequency in spoken English in a naturalistic context. 
The way BP interlanguage realizes the retroflex liquid can cause misunderstanding and may sound even 'funny' to native English speakers when Brazilians say things such as ['hepi] for rap, which sounds like the word happy. Miscommunication occurs and this may be perceived as one of the most problematic features for many Brazilians. However, according to some native speakers who heard the participant's recording, miscommunication is not likely to occur when a flap is produced instead of a retroflex after a consonant in the same syllable (e.g., the participant surfaces country as ['kantri]).

The participant, at times, drops the retroflex liquid at the end of a word when preceded by a mid back tense vowel [o]. Dropping the postvocalic $[\mathrm{r}]$ is not only a feature of the participant's interlanguage. According to Labov (1966, as cited in Wardhaugh, 2002), the lower classes in New York tend to drop the postvocalic [r]. Also, Received Pronunciation (RP), highest prestige accent in Southern England, is non-rhotic (Wardhaugh). Reduced / $\mathrm{r} /$ or nonexistent final / $\mathrm{r} /$ can also be heard in places such as New York, Boston, New Jersey, and the South of the United States. Dropping the final retroflex liquid is not a unique phenomenon of an IL. It can convey social meaning, but it does not cause misunderstanding.

\subsection{The syllabic / 1 / and the dark / 1 /}

In English, the syllabic / 1/ occurs "at the end of a word when immediately after a consonant" (Ladefoged, 2006, p. 73). It constitutes a weakly stressed syllable following a strong one (e.g., cattle surfaces as ['kæt1). The dark $/ 1 /$, which is the velarized $/ 1 /$, occurs after a vowel or before a consonant at the end of a word (e.g., full surfaces as ['ful] and talc surfaces as ['tæłk]) (Ladefoged).

Celce-Murcia et al. (1996) mention that "the postvocalic final /1/ sometimes assumes an / $\mathrm{v} /$-like quality" for some learners of English. They add that "this is similar to what happens to postvocalic /1/ in Brazilian Portuguese" (p. 106). In Portuguese, the phoneme /1/ may surface as a glide [w] at the end of a syllable (e.g., Brasil surfaces as [bra'ziw]). It can also surface as a dark $/ 4 /$; however, this only occurs 
in European Portuguese and certain dialects in the South of Brazil (Cristófaro Silva, 2007).

\section{Table 9}

Syllabic / / in word-final position

\begin{tabular}{l|l}
\hline Total words with /1/ & $/ 1) /$ surfaced as [ow] \\
\hline 12 & $12(100 \%)$ \\
\hline
\end{tabular}

As shown in Table 9, the participant realizes /1/ as a diphthong, a back vowel followed by a glide [ow]. For example, the words travel and people surface as ['travow] and ['pipow] respectively. The dark / 1 / also surfaced as a glide, as shown in Table 10. For example, the words well and feel are surfaced as ['wew] and ['fiw]. The participant seems to be applying phonetic restrictions from her L1 when speaking English.

\section{Table 10}

Dark / / / in word-final position

\begin{tabular}{l|l}
\hline Total words with /4/ & $/$ A / surfaced as [w] \\
\hline 5 & $5(100 \%)$ \\
\hline
\end{tabular}

BP learners tend to realize distinct pairs with the same pronunciation. For example, both go ['gow] and goal ['gowl] tend to be surfaced as ['gow] by BP speakers. This phonological process may cause miscommunication. Native speakers may have trouble in understanding what the non-native speaker is saying.

\section{Conclusion}

Through the phonological analysis of a BP learner of English, interesting aspects of her IL are revealed. Devoicing takes place when the participant pronounces final obstruents. This process seems to be 
more universal and independent, not related to L1 (Yavas, 1994). It may also be argued that devoicing is part of the IL development sequence in which unmarked features are acquired first.

The participant applies either epenthesis or reduction when facing consonant clusters that are not permissible in her L1. The use of these strategies reveals the influence of L1 in her IL.

The participant replaces interdentals with stops, which is a strategy used not only by BP speakers of English, but also by speakers whose L1 is not Portuguese and by native speakers of some dialects of English. BP speakers may perceive stops and interdentals as having similar sounds and, therefore, they employ stops (and not other sounds, such as fricatives, for example). Writing may also play a role in the IL process (Silveira, 2007).

Other aspects of the participant's IL suggest strong influence of her L1. For example, a flap surfaces, instead of the retroflex liquid, in consonant clusters in onset position, the syllabic / $1 /$ surfaces as a diphthong [ow], and the dark / $\mathrm{A} /$ as a glide [w]. These features reveal the participant's tendency to apply the rules of her L1 in her L2.

Some aspects of the participant's IL are found in some dialects of English. For example, released final stops, cluster reduction, the dropping of the final retroflex liquid, and the replacement of interdentals with other phonemes. Although these types of variation do not reflect standard English, they are not a serious source of misunderstanding since there are dialects of English that employ them. However, replacing a retroflex liquid with a glottal as well as producing a glide [w] where the syllabic $/ 1$ / or dark $/ 4$ / should be produced can cause miscommunication. Overcoming these two aspects of the IL may be considered the greatest challenge for BP learners of English.

The influence of L1 as well as universal aspects of language acquisition seem to explain a great deal of the participant's IL phonology process. However, other aspects may be as relevant, such as the acquisition of words/phrases as chunks, frequency, developmental sequences of some aspects of IL which may encompass universal aspects as well as variants according to L1, and the influence of orthographic knowledge. 
This research has limitations, the main one being the limited number of participants. Future research involving a larger number of participants is necessary in order to obtain a more comprehensive understanding of the phenomena investigated here. The methodology applied in this research is free speech. However, "different dataelicitation techniques may yield different conclusions" (Gass \& Selinker, 2001, p. 233). Future research may consider different types of tasks in order to investigate possible interactions between variation and language acquisition by learners who have acquired English mostly in a naturalistic environment. The comparison between the IL of BP learners of English who have acquired the language in a more naturalistic environment and those learners who have acquired it in formal settings may also be of interest for future research. The extent to which perception affects production in the development of the IL may also be a matter for future research.

Finally, aspiration and devoicing may be part of developmental sequences in IL in which more complex features are acquired as the learners receive more input and progress towards the target language. In order to investigate the presence of developmental sequences in IL of BP learners, longitudinal studies should be conducted.

\section{References}

Archibald, J. (1998). Second language phonology. Philadelphia: John Benjamins.

Baptista, B. O. (1992). The acquisition of English vowels by eleven Brazilian Portuguese Speakers: An acoustic analysis. Unpublished doctoral dissertation, University of California at Los Angeles.

Celce-Murcia, M., Briton, D. M., \& Goodwin, J. M. (1996). Teaching pronunciation. A reference for teachers of English to speakers of other languages. Cambridge: Cambridge University Press. 
Corder, S. P. (1967). The significance of learner's errors. International Review of AppliedLinguistics in Language Teaching, 5, 161-170.

Cristófaro Silva, T. (2007). Fonética e fonologia do português (9th ed). São Paulo: Editora Contexto.

Cruz, N. C. (2005). Minimal Pairs: Are they suitable to illustrate meaning confusion derived from mispronunciation in Brazilian learners' English? Language Ensino, 8, 171-180. Retrieved April 26, 2008, from http://rle.ucpel.tche.br/php/edicoes/ v8n2/neide_cruz.pdf.

Delatorre, F., \& Koerich, R. D. (2004). Brazilian EFL learners' epenthesis production on English words ending in-ed. II Academic forum, Universidade Federal de Santa Catarina. Retrieved November 15, 2007, from www.cce.ufsc.br/pgi/ academicforumFernanda.pdf.

Eckman, F. (1977). Markedness and the contrastive analysis hypothesis. Language Learning, 27, 315-330.

Faria, A. (2003). Applied Phonetics: Portuguese Text-to-Speech. Retrieved January 08, 2008, from www.icsi.berkeley.edu/ arlo/ling110/proj.pdf.

Finegan, E. (2004). Language: Its structure and use (4th ed). Boston: Thomson Wadsworth.

Finegan, E. \& Rickford, J. R. (Eds.). (2004). Language in the USA. Cambridge: Cambridge University Press.

Gass, S. M., \& Selinker, L. (2001). Second language acquisition: An introductory course ( $2^{\text {nd }}$ ed). Mahwah, NJ: Laurence Erlbawn and Associates.

Keys, K. (2002). First language influence on the spoken English of Brazilian students of EFL. ELT Journal, 56(1), 41-46.

Koerich, R. D. (2002). Perception and production of word-final vowel epenthesis by Brazilian EFL students. Unpublished doctoral dissertation. Florianópolis: Universidade de Santa Catarina.

Ladefoged, P. (2006). A course in phonetics ( ${ }^{\text {th }}$ ed). Boston: Thomson Wadsworth.

Lado, R. (1957). Linguistics across cultures. Ann Arbor: University of Michigan Press. 
Lightbown, P. M., \& Spada, N. (2006). How languages are learned ( $3^{\text {rd }}$ ed). Oxford, England: Oxford University Press.

Monahan, P. J. (2001). Brazilian Portuguese coda condition constraint transfer into L2 English. Journal of Undergraduate Research, University of Florida, 3(4). Retrieved November 12, 2007, from www.clas.ufl.edu/jur/200112/papers/ paper_monahan.htm.

Mattoso Câmara Jr., J. (1984). Estrutura da língua portuguesa (14 ${ }^{\text {th }}$ ed). Petrópolis, Rio de Janeiro: Vozes.

Selinker, L. (1972). Interlanguage. International Review of Applied Linguistics, 10/2, 209-231.

Silveira, R. (2007). Investigating the role of orthography in the acquisition of L2 pronunciation: A case study. In A. S. Rauber; B. O. Baptista, \& M. A. Watkins (Eds.), Proceedings of the New Sounds 2007: 5th International Symposium on the acquisition of second language speech (pp. 459-472). Florianópolis: Universidade Federal de Santa Catarina.

Silveira, R. \& Baptista, B. O. (2008). A pesquisa em interfonologia: Percepção, produção e ensino. Anais do IX Congresso Internacional de Fonética e Fonologia, 2006. CD. Belo Horizonte, Brazil.

Wardhaugh, R. (2002) An introduction to sociolinguistics ( $4^{\text {th }}$ ed). Oxford: Blackwell.

Yavas, M. (1994). First and second language phonology. San Diego, California: Singular Publishing Group, Inc.

\section{Acknowledgment}

I would like to thank Prof. Rosane Silveira (UFSC/CAPES), who kindly read a previous version of this article and offered me valuable insights. I also would like to thank Prof. Howard Williams (Teachers College Columbia University), who helped me to better understand the intriguing world of phonemes. I am grateful to the participant, who enthusiastically volunteered to participate in this study. Finally, I would like to thank Jim Osborne, whose suggestions in revising the article were priceless. 